МЕСТНОЕ САМОУПРАВЛЕНИЕ КАК СОСТАВЛЯЮЩАЯ ПОЛИТИЧЕСКОГО УПРАВЛЕНИЯ: ТЕОРЕТИКО-МЕТОДОЛОГИЧЕСКИЙ АСПЕКТ

DOI: $\underline{\text { 10.31618/ESU.2413-9335.2020.2.74.736 }}$

Шумилина Анастасия Борисовна

Доцент кафедры «Коммерческое и предпринимательское право» ФГБОУ ВО "Донской государственный технический университет»;

дочент кафедры «Гражданское право и прочесс» ФГБОУ ВО «Ростовский государственный университет путей сообщения»

кандидат юридических наук

Артюхин Олег Александрович

дочент кафедры политологии и этнополитики

Южно-Российского института управления -

филиала Российской академии народного хозяйства и государственной службь при Президенте Российской Федераџии, доиент кафедры теории и истории государства и права ФГБОУ ВО «Донской государственный технический университет" кандидат политических наук, доиент

Крицкая Анна Александровна

дочент кафедры политологии и этнополитики

Южно-Российского института управления филиала Российской академии народного хозяйства и государственной службь при Президенте Российской Федераџии кандидат политических наук

\title{
LOCAL GOVERNMENT AS THE POLITICAL MANAGEMENT: THEORETICAL-METHODIC
} ASPECT

\author{
Shumilina Anastasia Borisovna \\ Associate Professor of Commercial and Entrepreneurial Law \\ at Donskoy State Technical University; \\ Associate Professor of Civil Law and Process \\ at Rostov State University \\ candidate legal sciences \\ Artyukhin Oleg Alexandrovich \\ Associate Professor, Department of Political Science and Ethnopolitics \\ of the South Russian Institute of Management- \\ a branch of the Russian Presidential Academy \\ of National Economy and Public Administration, \\ Associate Professor, Department of Theory and History of State and Law, \\ Don State Technical University \\ candidate of political sciences, associate professor \\ Kritskaya Anna Alexandrovna \\ Associate Professor, Department of Political Science and Ethnopolitics \\ of the South Russian Institute of Management- \\ a branch of the Russian Presidential Academy \\ of National Economy and Public Administration \\ candidate of political sciences
}

\section{АННОТАЦИЯ}

В статье рассматриваются особенности организации местного самоуправления в современной России, исследуются особенности его взаимодействия с государственной властью, выявляются сущностные характеристики местного самоуправления, определяется его роль в системе политического управления и публичной власти

ABSTRACT

The article examines the peculiarities of the organization of local government in modern Russia, explores the peculiarities of its interaction with the state government, identifies the essential characteristics of local government, defines its role in the system of political governance and public power

Ключевые слова: местное самоуправление, политическое управление, государственное управление, местная власть, публичная власть.

Key words: local government, political governance, public administration, local government, public power.

Институт местного самоуправления является одним из важнейших элементов механизма политического управления современными обществами. Развитие любого государства не 
стихийно, оно направляется органами государственной власти, возникшими в результате институционализации политической системы. Большинство современных стран являются сложными социально-экономическими системами, которые предполагают децентрализацию функций политического управления. В этих системах на каждом уровне управления государственные служащие несут ответственность за принимаемые решения, имеют свои полномочия и обязанности, а также ресурсы для их выполнения. Стоит отметить, что в системе властных отношений местное самоуправление занимает важное место, так как именно через него, во-первых, принимаются решения на местном уровне и, во-вторых, именно через него транслируются политические решения на местный уровень.

Анализируя научно-теоретические подходы к исследованию местного самоуправления, стоит отметить, что в современной политологии и праве отсутствует единый подход к определению роли органов местного самоуправления, их инструментов и методов взаимодействия с населением. Начиная XVII - XVIII вв. вопросы самоуправления обсуждались в политических и правовых учениях французских просветителей и английских либералов, в идеях общественного договора, естественных прав личности и автономной общины, идеях представительного правления и разделения властей, определивших характер различных концепций местного самоуправления. [1,С,78.]

При этом отмечается многогранность понятия «местное самоуправление». В политических и правовых исследованиях[2,С,480.] отмечаются трехвекторность по следующим направлениям: вопервых, самостоятельность принятии решений, касающихся местных вопросов, во-вторых, реализации властных полномочий и, в-третьих, в защите интересов местных сообществ (гражданских общин). При этом отсутствие единых подходов к МСУ проявляется как в правовых документах, так и судебной практике.

Система местного самоуправления является одной из фундаментальных основ функционирования демократического общества и государства. Современные тенденции трансформации политических институтов и целостных политических систем направлены на плавный переход от централизованных вертикальных систем управления, присущих предыдущим столетия, к системам горизонтального типа, к распределению сфер принятия решений и увеличения числа субъектов в политических процессах.

В современной России процесс реформации всех сторон общественной жизни проходят в условиях кардинального изменения гражданского сознания. Стоит признать, что уровень развития общественной жизни на современном этапе опережает уровень функционирования бюрократической системы в России, демократические формы организации общества сталкиваются с консервативным устремлением к упрощенному понимаю отношения человека и гражданского общества с государством.

В этом ключе на первый план выходит важность правильного осознания особенностей местной власти, как института, который сочетает в себе два начала: общественное и государственное. Проблемы, возникающие во взаимоотношении этих двух начал, имеют существенное влияние на политические процессы в государстве и на последствия их протекания.

За последние 20 лет в России прошли сразу несколько крупных реформ местного самоуправления, вся основная нормативноправовая база института создавалась именно в этот период.

В основе МСУ лежит особый способ принятия решений, [3,C,5.] именно непосредственное участие местного населения отличает местное самоуправления от других механизмов политического управления. В современном обществе МСУ воспринимается как главное условие формирования и развития гражданского общества. Современная политическая и юридическая наука признает систему местного самоуправления неотъемлемым признаком демократического государства. [4,С,113.]

В российской научной литературе термин «местное самоуправление» появился в XIX веке. Его толкование связывалось напрямую с пониманием «самоуправление». Одно из первых понятий, сформулированных А.И Васильчиковым, определяло самоуправление как «такой порядок управления, при коем местные дела и должности замещаются местными жителями». [5,С,38.]

Особенности местного самоуправления во многом предопределяются национальногосударственными традициями организации публичной власти в разных странах.

Среди множества концепций МСУ можно выделить:

1. Теорию свободной общины (О. Ресслер, М. Аренс, О. Лабанд, Э. Мейер и др.)

2. Общественную теорию (Р. Моль, О. Ресслер, А. И. Васильчиков, В. Н. Лешков и др.)

3. Государственную теорию (Л. Штейн, Н.И. Лазаревский, А.Д. Градовский, В. П. Безобразов и др.) и др.)

4. Политическую теорию (Р. Гнейст, Л. Штейн

5. Дуалистическая теория (О. Зеевальд, Б. Н. Чичерин, Т. Маунц и др.)

Современные подходы к местному самоуправлению отражены в Европейской хартии местного самоуправления, принятой Советов Европы 15 октября 1985 года.

Хартия определяет местное самоуправление следующим образом:

«1. Под местным самоуправлением понимается право и способность органов местного самоуправления регламентировать значительную часть публичных дел и управлять ею, действуя в 
рамках закона, в соответствии со своей компетенцией и в интересах местного населения.

2. Это право осуществляется советами или собраниями, состоящими из членов, избранных путем свободного, тайного, прямого, равного и всеобщего голосования. Советы или собрания могут располагать подотчетными им исполнительными органами. Это положение ни в коей мере не исключает обращения к собраниям граждан, референдуму или любой другой форме прямого участия граждан там, где это допускается по закону». [6]

Органы местного самоуправления (далее МСУ) в многосоставном федеративном государстве, каковым является РФ, олицетворяют собой важнейший уровень управленческоорганизационного, политико-управленческого воздействия на общественно-политические отношения.

С одной стороны, МСУ направлено, прежде всего, на решение жизненных задач населения, т.е. обеспечение витальных потребностей жителей муниципальных образований. [7] В соответствии с законодательством России МСУ предполагает, в первую очередь, организацию и самоорганизацию граждан для участия в реализации муниципальных целевых программ и инициации акций и мероприятий широкого хозяйственного спектра. [8]

Вместе с тем, практика демократических преобразований, которая осуществляется на местном уровне, предъявляет более масштабные требования к МСУ и предполагает расширительное толкование его функций. Очевидно, что органы МСУ воздействуют не только на хозяйственную жизнь местного сообщества, но и на общественнополитические отношения, на общественнополитическую жизнь населения муниципального образования. Поэтому закономерна постановка такой проблемы, как возможности, принципы, направления, формы и методы политического управления силами органов МСУ или же в ходе осуществления реформы МСУ.

Значимость такого управления в РФ обусловлена не только общими потребностями демократических преобразований и политической модернизацией. Такое управление обусловлено также и тем, что Россия - это многосоставная полиэтничная федерация, в которой каждый уровень управления имеет важное политическое значение. Каждый уровень управления федеральный, региональный и местный - имеет собственные ресурсы для обеспечения дальнейшей демократизации политической системы, политических институтов.

В этом плане МСУ является «особым видом самоуправления, составляющей общественного самоуправления и публичного управления». [9,С,35.] Поэтому стоит подчеркнуть, что, несмотря на выраженную хозяйственную направленность деятельности МСУ, оно как составляющий компонент конституционного строя России, осуществляет и политическое управление.
Ресурсы МСУ в этом направлении не проявляются так, как например, проявляются ресурсы органов власти. Но в то же время, в федеративном государстве, где общественнополитические отношения существенно дифференцированы по регионам в связи со многими обстоятельствами - экономическими, социальными, политическими, а также и в связи с этнокультурными и этнополитическими различиями, роль МСУ актуализируется именно в сфере политического управления. Несмотря на общие принципы политической жизни, на общность таких процессов, как партогенез и гражданское структурирование в масштабе федерации, в регионах наличествуют особенности политической самоорганизации граждан, самовыражения политической элиты, осуществления электорально-избирательных пулов.

Поэтому МСУ, наряду с центральной и региональной властью, выступает важнейшим звеном в осуществлении власти и управления, которые в РФ распределены в соответствии с общими принципами государственного устройства, а также и в связи с конкретным административнотерриториальным устройством России.

В связи со сложностями и противоречиями современного федеративного процесса, а также в связи с проблемами административной реформы роль МСУ усиливается именно в стабилизации общественно-политических отношений. В связи с этом Н. Салищева и Е. Амбросимова отмечают, что органы МСУ являются акторами не только хозяйственной жизни, но и акторами политического управления на местах.[10] Все первичные требования населения, все проблемы, недовольства и претензии к власти, в том числе и к федеральной, проявляются, прежде всего, на местном уровне и адресуются, прежде всего, органам МСУ.

В этой связи сам процесс МСУ должен быть максимально включен в федеральный, региональный общественно-политический процесс, а также, чтобы процесс общественнополитической самоорганизации граждан на местах был максимально оптимизирован в контексте федеративного и регионального общественнополитического процесса. Политическое управление на уровне МСУ ориентировано на стабилизацию ситуации на местах, а также и на «создание работающей системы институтов местной власти...», которая является «неотъемлемой и весьма важной частью политической системы страны». [11]

МСУ имеет широкие ресурсы политического управления на местном уровне именно в силу максимального знания настроений, интересов, социального самочувствия и социальных ожиданий населения. В этой связи органы МСУ призваны акцентировать свою роль в системе отношения федерации и регионов, а также в системе регионов между собой - т.е., как по вертикали, так и по 
горизонтали. Для этого в РФ созданы все условия прежде всего, правовые и политические. [12]

В заключение необходимо отметить, что проблема взаимоотношений государственной власти и местного самоуправления до сих пор требует тщательного теоретико-методологического осмысления, политического анализа и дальнейшего развития. Самоуправление в Российской Федерации не может развиваться само по себе, без взаимосвязи с государственной властью. Эта взаимосвязь находит отражение во многих нормативно-правовых актах, однако по многих вопросам в законодательстве наблюдаются пробелы. Обеспечение сочетания государственной власти с местным самоуправлением - чрезвычайно важная задача в условиях современного кризиса. Поэтому в проекте изменений в Конституцию РФ местное самоуправление включается в единую систему публичной власти.

\section{Литература:}

1. АндриченкоЛ.В. Новое о местном самоуправлении / Л.В. Андриченко//Журнал российского права. - 2014. - № 11. - С. 163 - 166; Атаманчук Г. Государственное управление. Организационно-функциональные вопросы / Г. Атаманчук. - М.: Экономика. - 2010.

2. Ковешников Е.М. Государство и местное самоуправление в России: теоретико-правовые основы взаимодействия. - М.: Издательство НОРМА. - 2012. - С.272.; Игнатов В.Г., Рудой В.В. Местное самоуправление. - Изд. 3-е, перераб. и доп. - Ростов нЏД: Феникс. - 2014.

3. Зотов В.Б. Система муниципального управления: учебник для ВУЗов: 3-е издание. // Санкт-Петербург. Издательство: «Питер Пресс». 2007.

4. Акмалова А.А. Актуальные проблемы муниципального права России: Курс лекций. // Москва: Издательство РАГС. - 2009.

5. Васильчиков А.И. О самоуправлении: сравнительный обзор русских и иностранных общественных учреждений.// СПб. - 1912. - Т. 1.
6. Европейская хартия местного самоуправления ETS № 122 (Страсбург, 15 октября 1985 г.) // [Электронный ресурс]. - Режим доступа: http://www.base.garant.ru/2540485/\#ixzz4aXbfEWkJ (дата обращения 15.10.2019)

7. Анимица А.Г. Основы местного самоуправления. - М., 2000; Клешко А.М., Иванов А.Ю. Реформа местного самоуправления // Депутатские вести: Бюллетень Ассоциации по взаимодействию представительных органов государственной власти и местного самоуправления Красноярского края. 2003. 16 янв.

8. Местное самоуправление. Энциклопедия / Под общ. ред. В.Б. Зотова- Ростов/нД, 2010.

9. Васильев В.И. Муниципальное право России. - М.: Юстицинформ, 2008.

10. Салищева Н., Абросимова Е. Административная реформа и административный процесс в России // Сравнительное конституционное обозрение. - 2005. - № 3.

11. Доклад о развитии местного самоуправления В Российской Федерации и задачах Всероссийского Совета местного самоуправления» - [Электронный ресурс]. - Режим доступа: http://www.vsmsinfo.ru/dokumenty-imaterialy/materialy-proshedshikh-meropriyatij/2710doklad-o-razvitii-mestnogo-samoupravleniya-vrossijskoj-federatsii-i-zadachakh-vsms-proektutverzhden-na-zasedanii-rasshirennogo-byurotsentralnogo-soveta-vsms-31-05-2011

12. Шеремет К.Ф. Становление правовой базы местного самоуправления в Российской Федерации. Местное самоуправление: современный российский опыт. - М., 1998; Децентрализация государственной власти и местное самоуправление: проблемы реализации // Совместные исследования. - М.: Изд-во РАГС, 2007.

13. Шумилина А.Б. Политико-правовые технологии обеспечения корпоративных интересов в России. Ростов-н/Д., 2018. 